\title{
A 17-month-old girl presented with jaundice, hepatosplenomegaly, ascites and scaly erythematous skin lesion
}

\author{
Sayma Rahman Munmun, A. S. M. Bazlul Karim, Rezina Parveen, Md. Benazamin, Md. Shafikul \\ Alam Tanim and Manmohan Bir Shrestha
}

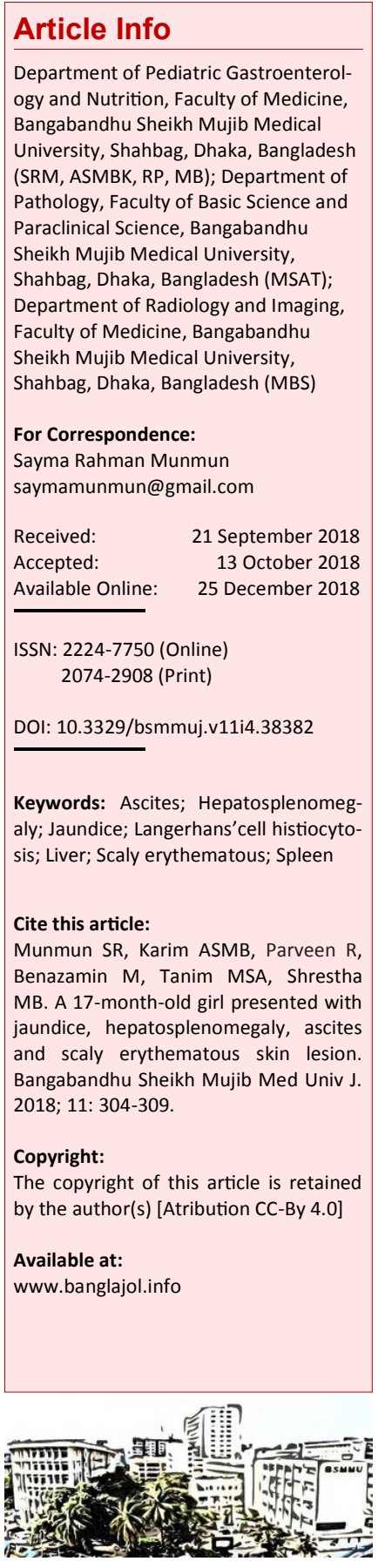

\section{Presentation of Case}

Dr. Rezina Parveen: A 17-month-old girl, only issue of non-consanguineous parents, hailing from Sirajgonj, Bangladesh immunized as per EPI schedule got admitted to the inpatient department with the history of abdominal distension, jaundice, not growing well along with scaly skin lesion over scalp, chest, palm and sole for 9 months. She was reasonably well 9 months back. Then she developed abdominal distention which was increasing day-by-day associated with gradually deepening jaundice. There was also a history of irregular fever and cough for 1 month. Fever was high-grade irregular in nature, subsided by taking antipyretics in conjunction with non-productive cough. There was no history of contact with the tuberculosis patient, any surgery or dental procedure, family history of liver disease, but the history of one unit blood transfusion.

On physical examinations, she was dyspnic, febrile, mildly pale and icteric (Figure 1). The respiratory rate was 48 breaths/ $\mathrm{min}, \mathrm{SPO}_{2} 95 \%$ without $\mathrm{O}_{2}$. The blood pressure was within normal limit. The digital clubbing, multiple red papular non-itchy skin lesion on both palm and sole and diffuse scaly lesion on the scalp, and BCG mark were present. There was no lymphadinopathy. She was severely wasted, stunted and underweight. On systemic examination, the abdominal distention with huge hepatosplenomegaly and ascites were found. The wheeze and crackles were present on both lung fields.

The laboratory data (Table I) showed anemia (hemoglobin: $8.6 \mathrm{~g} / \mathrm{dL}$ ), markedly raised erythrocyte sedimentation rate $\left(120 \mathrm{~mm}\right.$ in $1^{\text {st }}$ hour), grossly impaired liver function (serum alanine aminotransferase: $238 \mathrm{U} / \mathrm{L}$, total bilirubin: $9.2 \mathrm{mg} / \mathrm{dL}$, serum albumin $27 \mathrm{~g} / \mathrm{L}$ ). The X-ray chest showed consolidation (Figure 2). The Mantoux test was $2 \mathrm{~mm}$.

The abdominal ultrasonography showed heterogenous echotexture of the liver with multiple nodular lesion. After evaluating the clinical data, physical findings and investigation results, the case was provisionally diagnosed.

\section{Provisional Diagnosis}

Chronic liver disease with portal hypertension with pneumonia

\section{Chronic liver disease}

The chronic liver disease is a disease process of the liver that involves a process of progressive destruction and regeneration of liver parenchyma leading to fibrosis and cirrhosis and in some cases hepatocellular carcinoma. Unlike adults, there is no time duration of illness that defines the chronic liver disease. All the inherited metabolic and genetic conditions even when diagnosed at birth could have the advance liver disease. The common causes of chronic liver diseases in children are infection (chronic hepatitis B or C), metabolic liver disease (Wilson disease, $\alpha_{1}$ antitrypsin deficiency, glycogen storage disease, lipid abnormalities, cystic fibrosis), developmental/genetic (biliary atresia, congenital hepatic fibrosis, Alagille syndrome), immune-related (autoimmune hepatitis, sclerasing cholangitis), vascular (Budd chiari syndrome, hepatic venoocclusive disease, portal vein thrombosis), etc.

Patients with chronic liver disease clinically may present with anemia, jaundice, bleeding manifestations and other stigmata of chronic liver disease (palmar erythema, nail clubbing, spider nevi), ascites, features of hypersplenism with splenomegaly. 1 In this case, anemia, jaundice, clubbing, hepatoslenomegaly and ascites are in favor of chronic liver disease but the characteristic skin lesion and lung findings are against the diagnosis of chronic liver disease.

\section{Differential Diagnosis}

Dr. Md. Benzamin: The patient presented with jaundice, gradual abdominal distension and failure to thrive. There was a history of cough and irregular fever. The child was dyspneic, febrile, mildly pale and icteric. Digital clubbing 


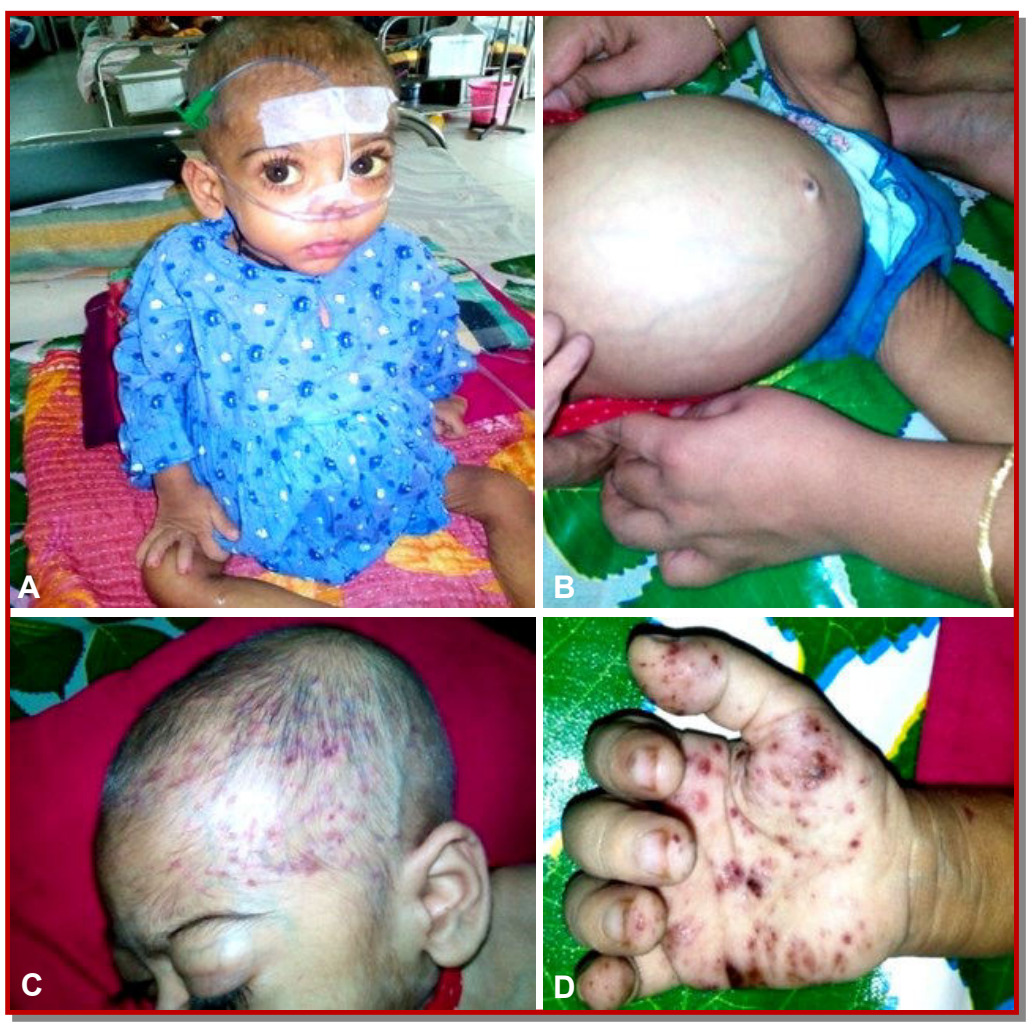

Figure 1: The patient with jaundice (A), abdominal distension (B), erythematous rash over scalp and face (C), and hand (D)

was present. She was severely wasted and underweight. On systemic examination, wheeze and crackles were present in both lung fields. Huge hepatosplenomegaly with ascites was also present. Investigations showed high erythrocyte sedimentation rate and consolidation on the chest X-ray. After evaluating the clinical data, physical findings and investigations report we differentially considered it as a case of disseminated tuberculosis. But there was no history of contact with the tuberculosis patient, BCG mark was present. There was no
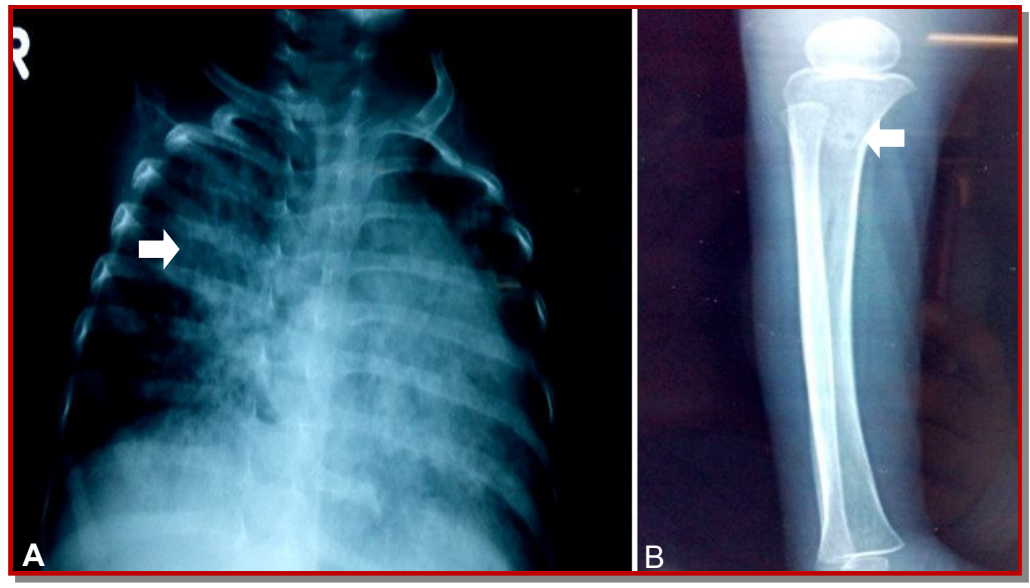

Figure 2: Consolidation of lungs (A) and lytic lesion over tibia (B) as shown by arrows lymphadenopathy and the Mantoux test was negative. These go against the diagnosis of tuberculosis.

\section{Tuberculosis}

Tuberculosis is an important global health problem and Bangladesh is one of the high tuberculosis burden countries in the world. It includes the pulmonary and extrapulmonary form. Studies from Bangladesh showed that extrapulmonary form is commoner in children.2,3 Disseminated tuberculosis is defined as tuberculous infection involving the bloodstream, bone marrow, liver, or involvement of two or more non-contiguous sites, or miliary tuberculosis. $\underline{4}$ It is a potentially life-threatening form of tuberculosis. $\frac{4,5}{5}$ The incidence of disseminated tuberculosis ranges from $1-3 \%$ of all tuberculosis cases. $.6,7$ It is common among the infants and children. 8

Dr. Sayma Rahman Munmun: After evaluating the patient's presenting features, physical findings and the laboratory test results she was considered for further investigation because the skin lesions remained unexplained. For this, the skin biopsy was done and the tissue was sent for histopathology.

Dr. Md. Shafikul Alam Tanim: The histopathological examination of the biopsy specimen taken from the scalp following anesthesia revealed mixed infiltrate of Langerhans cells, lymphocytes and occasional eosinophils in the upper dermis. However, a variable number of neutrophils and plasma cells were also found in many other cases. Immunohistochemical analysis was performed with antiCD1a, S100 and CD68 primary antibodies. Langerhans cells organized in groups and singly showed brown immunohistochemical stain for CD1a and S100 protein, but not for CD68 protein. In immunohistochemical examination, CD1a and S100 positivity confirmed the diagnosis of Langerhans cell histiocytosis (Figure 3).

Dr. Munmun: After getting the histopathology report, we did the skeletal survey to see the bone involvement. We also did the bone marrow puncture which was normal and planned for the liver biopsy but could not do that as because the parents did not give consent.

Dr. Manmohan Bir Shrestha: Patient's X-ray of the right leg revealed well-defined round intramedullary non-expansile lucent lesion with marginal sclerosis in the metadiaphyseal region of the proximal shaft of tibia. Radiological differentials for this type of lesion includes benign bone neoplasms (i.e. simple bone cyst, enchondroma, chondroblastoma), Brodie's abscess, Langerhans cell histiocytosis, brown tumor of hyperparathyroidism and metastasis. In Langerhans cell histiocytosis, the common locations include the skull and long bones. In the case of long bones, Langerhans cell 


\begin{tabular}{|c|c|c|}
\hline \multicolumn{3}{|c|}{ Table I } \\
\hline \multicolumn{3}{|c|}{ Laboratory investigations of the patient } \\
\hline Parameter & Findings & References \\
\hline Hemoglobin (g/dL) & 8.6 & $12.2-14.8$ \\
\hline WBC count $\left(\times 10^{9} / \mathrm{L}\right)$ & 10 & $4-10$ \\
\hline \multicolumn{3}{|l|}{ Differentials } \\
\hline Neutrophil (\%) & 65 & $40-80$ \\
\hline Lymphocyte (\%) & 28 & $20-40$ \\
\hline Eosinophil (\%) & 3 & $1-6$ \\
\hline Monocyte (\%) & 8 & $2-10$ \\
\hline Platelet count $\left(10^{9} / \mathrm{L}\right)$ & 150 & $150-400$ \\
\hline $\begin{array}{l}\text { Erythrocyte sedimentation rate } \\
\text { (mm in 1st hour) }\end{array}$ & 120 & $0-10$ \\
\hline Peripheral blood film & $\begin{array}{l}\text { Microcytic hypo- } \\
\text { chromic anemia }\end{array}$ & \\
\hline Serum bilirubin total (mg/dL) & 9.2 & $0-1$ \\
\hline Serum alanine transaminase (U/L) & 238 & $0-55$ \\
\hline Serum albumin $(\mathrm{g} / \mathrm{L})$ & 27 & $35-50$ \\
\hline Prothrombin time (sec) & 14 & $12-16$ \\
\hline INR & 1.2 & \\
\hline Mantoux test (tuberculin test) & Negative & \\
\hline Chest X-ray & $\begin{array}{l}\text { Consolidation in } \\
\text { both lung fields }\end{array}$ & \\
\hline X-ray skull (both view) & Normal & \\
\hline $\begin{array}{l}X \text { ray of both hip joint, knee joint } \\
\text { and ankle joint }\end{array}$ & Lytic lesion in right & hd left femur \\
\hline $\begin{array}{l}\text { Ultrasonography of whole abdo- } \\
\text { men }\end{array}$ & $\begin{array}{l}\text { Hepatomegaly with } \\
\text { with multiple ill def } \\
\text { lobes of the liver }\end{array}$ & $\begin{array}{l}\text { echotexture } \\
\text { odules in both }\end{array}$ \\
\hline Bone marrow study & $\begin{array}{l}\text { Mature marrow wit } \\
\text { hyperplasia }\end{array}$ & ase erythroid \\
\hline
\end{tabular}

histiocytosis usually involves diaphysis or metadiaphysis. Patient's chest X-ray anteroposterior view revealed almost round dense homogenous opacity in the right mid zone at suprahilar region, possibly consolidation.

Dr. Munmun: Radiological findings of the patient was also in favor of the Langerhans cell histiocytosis. After considering the history, physical examination, biopsy and immunohistochemistry findings we reached a diagnosis of Langerhans cell histiocytosis.

\section{Langerhans cell histiocytosis}

This is a rare disease of Langerhans cell where multiple systems like skin, bones, lymph nodes, pituitary gland, bone marrow, liver, spleen, lungs etc. can be affected. Langerhans cell histiocytosis was previously called histiocytosis $\mathrm{X}$, which included three entities named eosinophilic granuloma, Hand-Schuller-Christian disease, Letterer-Siwe disease. $.9-13$ These are, now, replaced by singlesystem single site, single-system multisite, and multisystem disease. $.14-17$

\section{Single-system disease}

Single-system disease is the commonest form (65\%).18-20 Single-system single site disease can be defined as involvement of one system with the unifocal lesion. The unifocal form is usually benign, affects older children and adults and is characterized by a solitary bone lesion, usually in the skull or spine.21 But less commonly it can also involve the skin, lymph node, lungs, hypothalamicpituitary/central nervous system, etc. According to the older terminology, the unifocal form corresponds to eosinophilic granuloma. When multiple sites of a single system is involved, then it will be termed as single-system multisite disease. Multifocal form of Langerhans cell histiocytosis is more invasive and affects infants and several bone lesions and involvement of the adjacent soft tissue are seen in it. This disease corresponds to Hand-SchullerChristian disease.22

\section{Multisystem disease}

Involvement of two or more organ/system is called multisystem disease. Multisystem disease can occur with or without the risk organ involvement. Bone marrow, liver, spleen and lungs are the high-risk organs, whereas skin, bones, lymph nodes, pituitary gland are recognized as low risk organs. $\frac{9,10,14,16}{\text { But }}$ lungs are not defined as risk organs. $\underline{23}$ The multisystem disease was previously called as Letterer-Siwe disease.

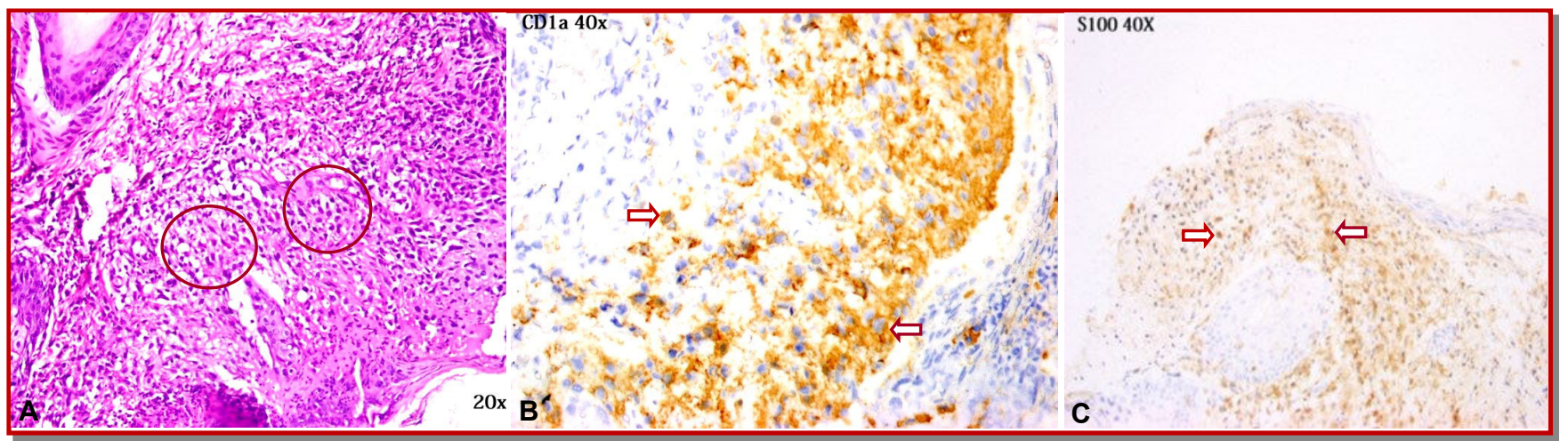

Figure 3: Histopathological feature of the skin biopsy H \& E 200x showing the Langerhans'cell histiocytosis (A, within circles); Immunohistochemistry 400x showing the CD1a (B) and 100x showing S100 (C) positivity (arrows) 
Our patient had liver, spleen, skin, lungs and bone involvement. So, she can be classified as multisystem disease with the risk organ involvement.

\section{Dr. Munmun's Diagnosis}

Langerhans'cell histiocytosis

\section{Discussion}

Dr. A. S. M. Bazlul Karim: Langerhans cell histiocytosis is an uncommon disease with an annual incidence of 2-9 per million of children. $.13,15,20,24$ In Bangladesh this disease is also diagnosed as only $2 \%$ of all childhood malignancies in a tertiary care center. 25 Here, clonal proliferation and migration of Langerhans cells occur, $\underline{\underline{2}}$ and these cells can infiltrate almost every tissue or organ. Langerhans cell histiocytosis was previously termed as histiocytosis $X$. The term $X$ denotes for its unknown origin. However, there is a paucity of information about the etiology and pathogenesis of Langerhans cell histiocytosis. It is not caused by a known infection, is not contagious, nor it is believed to be inherited. Although available data suggest that the growth of immature Langerhans cells possibly due to BRAF V600E gene mutation is responsible for about $50 \%$ of the cases there remain debates among the experts as to whether it is definitively cancer or not.27,28 It occurs at any age but it mostly affects children and young adults and the peak age is in between 1 to 4 years. $\underline{29}$ It is more common in boys. The male : female ratio is approximately 2:1. 30 The clinical presentation is highly variable which can range from self-limiting single system disease to potentially fatal multisystem disease. General symptoms are fever, lethargy, weight loss, growth failure, etc. More specific symptoms depend on the involvement of different organ and it includes painful bone lesion $(80 \%)$, seborrhoeic erythematous rash, hemorrhagic rash $(60 \%)$, swollen lymph nodes $(33 \%)$, feature of diabetes insipidus, short stature (25\%), hepatomegaly, liver dysfunction $(15 \%)$, anemia, jaundice, clubbing, proptosis, dental carries, splenomegaly, ascites, otitis media, cranial nerve palsy, etc. Young children often present with multisystem disease having fever and symptoms of failure in various organs. $.9,17$ The diagnosis of Langerhans cell histiocytosis is done on the basis of histological criteria determined by the Histiocyte Society in 1987.14 A definitive diagnosis includes identification of characteristic cells and the presence of markers eg. CD1a and/or CD207 (langerin). Other supportive investigations such as full blood count, liver function test, skeletal survey, ultrasonogram of abdomen etc. are done for the determination of disease extent and exclusion of other causes. Osteolytic bone lesions can be present in the skeletal survey and chest X-ray may show miliary motting. Magnetic resonance imaging and computed tomography scan may reveal infiltration in sella turcica. Assessment of endocrine function and bone marrow biopsy are also performed when indicated.

Treatment may be local or systemic, depending on the number and location of lesions. Systemic chemotherapy is the treatment of choice for single system multiorgan and multisystem disease as well as for special localizations. Systemic chemotherapy includes an initial intensive phase consisting of a standard two drugs regimen with vinblastine and prednisone for 6-12 weeks followed by maintenance therapy and the total treatment duration should be at least 12 months. $\underline{14}$ Salvage therapy with cytarabine, cladribine, clofarabine or combinations of these medications as well as bone marrow and/ or solid organ transplantation are the treatment of choice for the non-responders, progressive disease in a high-risk organ. $10,31-33$ Single system single site disease confined to the skin can be observed for spontaneous remission, if not then topical steroids, nitrogen mustard, psoralen combined with ultraviolet A therapy can be applied. For localized bone lesions surgical curettage is the usual treatment. Radiotherapy, intralesional steroids, bisphosphonates, early chemotherapy (vinblastine and prednisolone) are used for the bony lesions at crucial anatomical sites. Surgical excision is for single nodes with Langerhans cell histiocytosis. Regional node involvement may respond to a course of systemic steroids and chemotherapy for nodes resistant to treatment.

Systemic therapy with two-drug regimen (vinblastin, prednisolone) was started in our patient.

Dr. Kamrun Nahar: What endocrine problem(s) may occur in this patient?

Dr. Parveen: Endocrine involvement is uncommon in Langerhans cell histiocytosis. It can involve pituitary gland, hypothalamus, thyroid gland. The most common problem is diabetes incipidus. Others include short stature, hypothyroidism. The common symptoms are the excessive thirst, excessive urination, dehydration, fatigue, sweating, temperature changes, weight gain/loss, early or delayed/absent puberty.

Dr. Luthfun Nahar: What type of liver derangement occur?

Dr. Karim: Liver involvement is rare and can occur in the form of isolated hepatomegaly, sclerosing cholangitis, liver cirrhosis, etc. Involvement of hepatic hilar lymph nodes may give rise to hepatomegaly. The feature of organ dysfunction such as raised liver enzyme, hypoalbuminemia $(<30$ $\mathrm{g} / \mathrm{dL}$ ), clotting factor deficiencies and secondary edema, ascites, jaundice, etc. may accompany hepatomegaly. $\underline{14,16}$ Imaging studies of the liver (ultrasonography, computed tomography scan and 
magnetic resonance imaging) show low signal intensity along the biliary tracts or portal veins. $\underline{34}$ Involvement of the bile duct may cause cholestasis, sclerosing cholangitis (15-25\% of Langerhans cell histiocytosis children), biliary cirrhosis and organ damage that require transplantation. $.35,36$ In liver biopsy, histiocytes may not be present typically but periportal lymphocytic infiltrates, bile duct inflammation, loss of bile ducts may be seen. Prognosis is poor in liver involvement as it is a highrisk organ and 5-year survival rate is only $25 \% . \underline{20}$

Dr. Archana Shreshtha: Why there is growth failure?

Dr. Benzamin: Growth failure occurs due to the illness itself, treatments used and growth hormone insufficiency as a result of anterior pituitary involvement.

\section{Dr. Mohua Mondol: What is Birbeck granule?}

Dr. Tanim: Rod or tennis racket-shaped membranebound cytoplasmic organelle solely found in Langerhans cells. Previously, it was the gold standard for the diagnosis of Langerhans cell histiocytosis but now they have been replaced by langerin, which is a cell-surface receptor that induces Birbeck granule formation. $\underline{31,37}$

\section{Dr. Parisa Marjan: What is the prognosis?}

Dr. Munmun: Prognosis for Langerhans cell histiocytosis may be both good or bad. It depends on the form of the disease (single system/multisystem) as well as risk organ involvement and response to chemotherapy. In unifocal Langerhans cell histiocytosis involving a bone or an isolated skin lesion, the prognosis is good. But recurrence can occur in nearly one-third of patients. $38 \mathrm{Bad}$ prognostic criteria includes multisystem disease, risk organ involvement, nonresponsive to chemotherapy etc. Prognosis of our patient was guarded as she had a multisystem disease with risk-organ involvement.

\section{Follow-up}

Unfortunately our patient expired after one and half months of starting chemotherapy.

\section{Final Diagnosis}

Langerhans'cell histiocytosis (multisystem disease)

\section{References}

1. Theise ND. Liver and gall bladder. In: Robbins and Cotran Pathologic basis of disease. Kumar V, Abbas AK, Aster JC (eds). 9th ed. Philadelphia, Elsevier Saunders, 2015, pp 825-35.
2. Islam Z, Sanin KI, Ahmed T. Improving case detection of tuberculosis among children in Bangladesh: Lessons learned through an implementation research. BMC Public Health. 2017; 17: 131.

3. Sultana AT, Gathia R, Huda MM, Begum JA, Kamruzzaman, Amin MR. Pattern of childhood tuberculosis among the patients admitted in Dhaka Shishu (Children) Hospital. Northern Int Med Coll J. 2017; 8: 213-15

4. Wang JY, Hsueh PR, Wang SK, Jan IS, Lee LN, Liaw YS, Yang PC, Luh KT. Disseminated tuberculosis: A 10 -year experience in a medical center. Medicine 2007; 86: 39-46.

5. Aye M, Cabot JSF, Baba S, Thanabalan MC, Chung SF. Disseminated tuberculosis: A case study. J Metabolic Synd. 2014; 3: 2.

6. Domínguez Fenolle $\mathrm{P}$, Cenarro Guerrero T, Rivas Chamorro A, Rituerto Gómez B, Franco López Y. Tuberculosis: Epidemiologic and clinical study of 268 paediatric patients. An Esp Pediatr. 1991; 35: 2630.

7. Ibe M, Mori M, Mitsuda T, Aihara Y, Yokota S. Analysis of children with tuberculosis in the past 20 years. Kansenshogaku Zasshi. 1997; 71: 513-21.

8. Sharma SK, Mohan A, Sharma A. Miliary Tuberculosis: A new look at an old foe. J Clin Tuberc Other Mycobact Dis. 2016; 3: 13-27.

9. Haupt R, Minkov M, Astigarraga I, Schäfer E, Nanduri V, Jubran R, Egeler RM, Janka G, Micic D, Rodriguez-Galindo C, Van Gool S, Visser J, Weitzman S, Donadieu J. Euro Histio Network. Langerhans cell histiocytosis (LCH): Guidelines for diagnosis, clinical work-up, and treatment for patient till age of 18 years. Pediatr Blood Cancer. 2013; 60: 175-84.

10. Minkov M. Multisystem Langerhans cell histiocytosis in children: Current treatment and future directions. Pediatr Drugs. 2011; 13: 75-86.

11. Margo CE, Goldman DR. Langerhans cell histiocytosis. Surv Ophthalmol. 2008; 53: 332-58.

12. Grana N. Langerhans cell histiocytosis. Cancer Control. 2014; 21: 328-34.

13. Postini AM, Brach del Prever A, Pagano M, Rivetti E, Berger M, Asaftei SD, Barat V, Andreacchio A, Fagioli F. Langerhans cell histiocytosis: 40 years' experience. J Pediatr Hematol Oncol. 2012; 34: 35358.

14. Minkov M, Grois N, McClain K, Nanduri V, Rodriguez-Galindo C, Simonitsch-Klupp I, Visser J, Weitzman S, Whitlock J, Windebank K. Langerhans cell histiocytosis. Histiocyte Society Evaluation and Treatmet Guidelines, Protocol, 2009.

15. Abla O, Egeler RM, Weitzman S. Langerhans cell histiocytosis: Current concepts and treatments. Cancer Treat Rev. 2010; 36: 354-59.

16. Donadieu J, Chalard F, Jeziorski E. Medical mana- 
gement of Langerhans cell histiocytosis from diagnosis to treatment. Expert Opin Pharmacother. 2012; 13: 1309-22.

17. Windebank K, Naduri V. Langerhans cell histiocytosis. Arch Dis Child. 2009; 94: 904-08.

18. Morren MA, Broecke KV, Vangeeebergen L, Sillevis -Smitt JH, Van Den Berghe P, Hauben E, Jacobs S, Van Gool SW. Diverse cutaneous presentations of Langerhans cell histiocytosis in children: A retrospective cohort study. Pediatr Blood Cancer. 2016; 63: 486-92.

19. Morimoto A, Ishida $Y$, Suzuki N, Ohga S, Shioda Y, Okimoto Y, Kudo K, Ishii E, Ohga S, Shioda Y, Okimoto Y, Kudo K, Ishii E. Nationwide survey of single-system single site Langerhans histiocytosis in Japan. Pediatr Blood Cancer. 2010; 54: 98102.

20. Alston RD, Tatevossian RG, McNally RJ, Kelsey A, Birch JM, Eden TO. Incidence and survival of childhood Langerhans cell histiocytosis in Northwest England from 1954 to 1998. Pediatr Blood Cancer. 2007; 48: 555-60.

21. Weitzman S, Egeler RM: Langerhans cell histiocytosis: Update for the pediatrician. Curr Opin Pediatr. 2008; 20: 23-29.

22. Khan A, Amin M, Karim B, Shalike N. HandSchuller-Christian disease. Bangabandhu Sheikh Mujib Med Univ J. 2017; 10: 185-88.

23. Braier J, Latella A, Balancini B, Castaños C, Rosso D, Chantada G, Ripoli M, Goldberg J. Outcome in children with pulmonary Langerhans cell histiocytosis. Pediatr Blood Cancer. 2004; 43: 765-69.

24. Zinn DJ, Chakraborty R, Allen CE. Langerhans cell histiocytosis: Emerging insights and clinical implycations. Oncol J. 2016; 30: 122-39.

25. Islam A, Eden T. Brief report on pediatric oncology in Bangladesh. South Asian J Cancer. 2013; 2: 10506.

26. Kilborn TN, Teh J, Goodman TR. Paediatric manifestations of Langerhans cell histiocytosis: A review of the clinical and radiological findings. Clin Radiol. 2003; 58: 269-78.

27. Jezierska M, Stefanowicz J, Romanowicz G, Kosiak W, Lange M. Langerhans cell histiocytosis in children: A disease with many faces. Recent advances in pathogenesis, diagnostic examinations and treatment. Adv Dermatol Allergol. 2018; 35: 6-17.

28. Shea CR, Boos MD. Langerhans cell histio- cytosis. Medscape. February 8, 2016; http:// emedicine.med scape.com/article/1100579overview.

29. Salotti JA, Nanduri V, Pearce MS, Parker L, Lynn R, Windebank KP. Incidence and clinical features of Langerhans cell histiocytosis in the UK and Ireland. Arch Dis Child. 2009; 94: 376-80.

30. Das A, Cader FA. A young male presenting with polyuria and unilateral exophthalmos. J Bangladesh Coll Phys Surg. 2015; 32: 241-43.

31. Morimoto A, Oh Y, Shioda Y, Kudo K, Imamura T. Recent advances in Langerhans histiocytosis. Pediatr Int. 2014; 56: 451-61.

32. Simko SJ, Garmezy B, Abhyankar H, Lupo PJ, Chakraborty R, Lim KP, Shih A, Hicks MJ, Wright TS, Levy ML, McClain KL, Allen CE. Differentiating skin-limited and multisystem Langerhans cell histiocytosis. J Pediatr. 2014; 165: 990 96.

33. Simko SJ, Tran HD, Jones J, Bilgi M, Beaupin LK, Coulter D, Garrington T, McCavit TL, Moore C, Rivera-Ortegón F, Shaffer L, Stork L, Turcotte L, Welsh EC, Hicks MJ, McClain KL, Allen CE. Clofarabine salvage therapy in refractory multifocal histiocytic disorders, including Langerhans cell histiocytosis, juvenile xantogranuloma and Rosai-Dorfman disease. Pediatr Blood Cancer. 2014; 61: 479-87.

34. Wong A, Ortiz-Neira CL, Reslan WA, Sharon R, Pinto-Rojas A, Kaura D, Anderson R. Liver involvement in Langerhans cell histiocytosis. Pediatr Radiol. 2006; 36: 1105-07.

35. Yi X, Han T, Zai H, Long X, Wang X, Li W. Liver involvement of Langerhans' cell histiocytosis in children. Int J Clin Exp Med. 2015; 8: 7098-106.

36. Braier J, Ciocca M, Latella A, de Davila MG, Drajer $\mathrm{M}$, Imventarza $\mathrm{O}$. Cholestasis, sclerosing cholangitis, and liver transplantation in Langerhans cell histiocytosis. Med Pediatr Oncol. 2002; 38: 178-82.

37. Lau SK, Chu PG, Weiss LM. Immunohistochemical expression of langerin Langerhans cell histiocytosis and non-histiocytic disorders. Am J Surg Pathol. 2008; 32: 615-19.

38. Yagci B, Varan A, Caglar M, Soylemezoglu F, Sungur A, Orhan D, Yalçin B, Akyüz C, Kutluk T, Buyukpamukçu M. Langerhans cell histiocytosis: Retrospective analysis of 217 cases in single centre. Pediatr Hematol Oncol. 2008; 25: 399-408. 